Sains Malaysiana 46(6)(2017): 933-943

http://dx.doi.org/10.17576/jsm-2017-4606-13

\title{
Seroprevalence of Brucellosis among Farmers and Veterinary Technical Staff in Peninsular Malaysia
}

(Seroprevalens Bruselosis dalam Kalangan Peladang dan Kakitangan Teknikal Veterinar di Semenanjung Malaysia)

P.H. BAMAiYi, L. HASSAN*, S. Khairani-BeJo, M. ZAinAlabidin, A. AdZHAR, N. MOKHTAR, M. RAMlAN, P. ChandraWAThani, N. Hamidah, N. Abdullah, A.M. Husna Maizura \& B.V. Khebir

\section{ABSTRACT}

A study was conducted to determine the seroprevalence and risk factors associated with brucellosis in farmers, veterinary technical staff and other volunteers in Peninsular Malaysia using the One Health concept. A cross sectional study design was employed to sample a population of farmers and Veterinary technical staff on a volunteer basis. The Brucella Coombs test was used to elucidate the seroprevalence of brucellosis in the sampled population and the associated factors and predictors for brucellosis. The seroprevalence of brucellosis among farmers and non-farmers (veterinary technical staff and others) of 446 people studied was $1.35 \%$ (95\% CI=0.28-2.42). Occupation, age and drinking unpasteurized milk were significant risk factors for brucellosis using multivariate logistic regression at $90 \%$ confidence level. The odds of having brucellosis increased by 7.19 times in farmers compared to non-farmers $(90 \%$ $C I=1.16,44.71)$, it increased 7.16 times in individuals 40 years and below compared with those above 40 years old $(90 \% \mathrm{CI}=1.16,44.41)$ and 4.45 times among those who drink unpasteurized milk compared to those who do not (90\% $C I=1.03,19.15)$. This study highlights the current state of human brucellosis in Malaysia among those groups that are occupationally at risk. A nationwide health education of the occupationally exposed population especially farmers may decrease the incidence of the infection and support the on-going eradication efforts of brucellosis in Malaysia.

Keywords: Brucellosis; farmers; Malaysia; seroprevalence; veterinary staff

\section{ABSTRAK}

Satu kajian telah dijalankan untuk menentukan seroprevalens dan faktor risiko kaitan antara bruselosis dalam kalangan peladang, pekerja teknikal veterinar dan sukarelawan di Semenanjung Malaysia menggunakan konsep One Health. Kajian keratan lintang digunakan untuk persampelan dalam populasi peladang dan pekerja teknikal veterinar secara sukarela. Ujian Coombs bagi Brucella digunakan untuk menjelaskan seroprevalens bruselosis dalam kalangan sampel dan kaitan antara faktor dan ramalan untuk bruselosis. Seroprevalens bagi bruselosis dalam kalangan peladang dan bukan peladang (pekerja teknikal veterinar dan sukarelawan) yang berjumlah 446 orang ialah 1.35\% (95\% CI=0.28-2.42). Pekerjaan, umur dan minum susu yang tidak dipasteur merupakan faktor risiko yang signifikan bagi bruselosis apabila diuji dengan regrasi logistik multivarian pada aras keyakinan 90\%. Ramalan untuk mendapat bruselosis meningkat sebanyak 7.19 kali dalam kalangan peladang berbanding bukan peladang $(90 \% \mathrm{CI}=1.16,44.41)$ dan 4.45 kali dalam kalangan mereka yang minum susu yang tidak dipasteur berbanding dengan yang tidak minum susu (90\% CI= 1.03, 19.15). Kajian ini menggambarkan keadaan semasa kejadian bruselosis dalam kalangan pekerja yang terlibat dengan perladangan. Pendidikan kesihatan perlu dijalankan dalam kalangan pekerja terutamanya peladang agar dapat menurunkan kadar jangkitan penyakit di samping sokongan berterusan dalam usaha pembanterasan bruselosis di Malaysia.

Kata kunci: Bruselosis; kakitangan veterinar; Malaysia; petani; seroprevalens

\section{INTRODUCTION}

Brucellosis is caused by Gram-negative coccobacilli bacteria and is the most common zoonotic infection worldwide with an estimated 500,000 new cases annually (Pappas et al. 2006). The disease infects goats, sheep, cattle, buffaloes, dogs, camels, marine animals and man (Dawood 2008; Nagalingam et al. 2012). There are 10 different species of Brucella but the most pathogenic of all the species and common cause of brucellosis in humans is Brucella melitensis (Pappas 2010). The organism can be transmitted from animals to man through the consumption of unpasteurized milk, cheese, other dairy products and contact with contaminated animal tissues. Therefore, those individuals working closely with animals such as farmers and veterinary staff are considered at a higher risk of brucellosis due to their occupation (Bikas et al. 2003; Makita et al. 2010).

Brucellosis has been reported from goats and other animals in Malaysia (Bamaiyi et al. 2012; KhairaniBejo et al. 2006; Shahaza et al. 2009) and the infection 
has continued to be persistent up to the present time (Bamaiyi et al. 2014). However, there have been limited reports on human brucellosis other than a few case reports (Jama'ayah et al. 2011; Sam et al. 2012). Even among those high risk individuals working closely with livestock, there is no information about the level of exposure that these individuals have had to the Brucella organisms. Since Brucella infection in the local livestock has been emerging in the past few years in Malaysia, it is worth investigating the serological evidence for the exposure to the Brucella organisms among workers with close contact to these animals. This study describes a cross-sectional study conducted among the veterinary technical staff and livestock farmers to determine the seroprevalence and risk factors of Brucella infection in the central states of Peninsular Malaysia. This study was undertaken as a collaborative effort between the Faculty of Veterinary Medicine Universiti Putra Malaysia (FPV, UPM), the Department of Veterinary Services Malaysia (DVS), Zoonosis Sector of the Ministry of Health Malaysia $(\mathrm{MOH})$ and the Veterinary Research Institute Ipoh Malaysia (VRI), following series of discussions about the unknown public health impact of brucellosis among high risk or occupationally exposed individuals in Malaysia and as an example of the one-health concept approach in tackling zoonotic infections.

\section{MATERIALS AND METHODS}

\section{STUDY AREA AND DATA COLLECTION}

Malaysia consists of 13 states and three federal territories and has a total land mass of 329847 square km (127350 square miles). Malaysia is separated by the South China Sea into Peninsular Malaysia and Malaysian Borneo (comprising of Sabah and Sarawak). Malaysia borders Thailand, Singapore, Indonesia and Brunei and is located at $2^{\circ} 30^{\prime}$ and $112^{\circ} 30^{\prime}$ (Bunnell 2004; Tiong-Sa et al. 2001). Livestock farming is one of the preoccupations of many farmers and investors in Malaysia with the livestock sector contributing about 7.6\% to the GDP of the Agriculture sector (Vu 2007). By the year 2010 about 545,682 goats; 134,408 sheep; 1,821,663 swine; 126,478 buffaloes and 912,230 cattle were present in the country mostly by importation from other countries (Anon 2011).

A set of structured closed-ended questionnaires (available on request) were administered via face to face interview by trained staff. The questionnaire sought information on the demography including age, gender, state, marital status, ethnicity, educational level, income and potential risk factors such as occupation, consumption of unpasteurized milk, type of animals kept, proximity to animal houses, cleaning of aborted foetus, assisting during parturition, knowledge of brucellosis transmission and symptoms of brucellosis. A set of structured closed-ended questionnaires (available on request) were administered via face to face interview by trained staff.

\section{STUDY DESIGN AND SAMPLE SIZE DETERMINATION}

States with relatively high seroprevalence rates for brucellosis in goats based on the analysis of the nationwide $B$. melitensis sero-surveillance information between 2000 and 2009 (available on request) were enrolled into the study. Three central states were identified namely Selangor, Negeri Sembilan and Pahang. A cross-sectional study was conducted independently within each selected state whereby farmers and veterinary technical staff of the Department of Veterinary Services of Malaysia were invited to participate in the study, in collaboration with the Ministry of Health Malaysia which was carrying out a routine surveillance for brucellosis, following an awareness seminar on brucellosis in livestock and its public health impact. This research was carried out in accordance with ethical procedure of the Ministry of Health Malaysia and the Department of Veterinary Services Malaysia joint committee. Informed written consent of all volunteers was obtained. This research was funded by the Universiti Putra Malaysia, Department of Veterinary Services Malaysia and the Ministry of Health, Malaysia.

This study was performed as part of the routine screening by the Ministry of Health for emerging zoonotic infection therefore blood samples were collected by trained medical personnel of the ministry. Participation was completely voluntary and individuals were asked to sign an informed consent form before the study begun.

Sample size was calculated using OpenEpi Epidemiologic statistics for Public Health software version 3.01 based on Sullivan et al. (2009) using the following equation:

$$
\begin{aligned}
\text { Sample size } n= & {\left[\operatorname{DEFF}^{*} \mathrm{~Np}(1-\mathrm{p})\right] / } \\
& {\left[\left(\mathrm{d}^{2} / \mathrm{Z}^{2}{ }_{1-\alpha / 2}^{*}(\mathrm{~N}-1)+\mathrm{p}^{*}(1-\mathrm{p})\right],\right.}
\end{aligned}
$$

where $\mathrm{n}$ is the sample size; $\mathrm{N}$ is the total number of people in the study; $p$ is the estimated prevalence of people with brucellosis in the states $(0.5)$; $d$ is the the precision or maximum acceptable error rate $(0.01) ; \alpha$ is the probability of Type I error (0.05); and $\mathrm{z}$ is 1.96 .

Based on this formula, at least 370 people were required for our study but up to 446 people were recruited into the study. Inclusion criteria were being a farmer or veterinary staff at the time of sampling, involvement in handling animals and willingness to be part of the study. Exclusion criteria were other professions and not being a farmer or Veterinary staff at the time of sampling.

\section{SAMPLE COLLECTION}

Participants from Selangor, Negeri Sembilan and Pahang states of Malaysia were invited to participate in the study by signing a written consent and filling of structured closed ended interviewer-administered questionnaires. The participants were sampled between June 2010 and August 2011 at the Department of Veterinary Services of the respective states and sometimes at home. Blood was collected by qualified medical personnel from the 
cephalic vein or median cubital vein of the left arm using sterilized syringes and needles and transferred to plain tubes. Collected blood was tested for brucellosis using the Brucella Coombs test which has a reported $100 \%$ specificity and sensitivity (Casao et al. 2004). The Coombs test is also called the antihuman globulin test or Indirect Coombs test. It is an extension of the Serum Agglutination Test (SAT) test and is used just like SAT to detect incomplete, blocking and non-agglutinating Immunoglobulin $\mathrm{G}$ (IgG). The SAT test involves the use of tubes to react a known standardized volume and concentration of whole Brucella cell suspension with a standardized volume of twice serum dilutions normally ranging from 1:20 to $1: 1280$. The suspension mixture was incubated for $24 \mathrm{~h}$ at $37^{\circ} \mathrm{C}$ and agglutination at the bottom of the tube was seen visually. The highest serum dilution that showed more than $50 \%$ agglutination was considered the agglutination titre. These SAT tubes containing serum dilutions with whole $B$. abortus and B. melitensis cells as antigens and that were negative after incubation for $24 \mathrm{~h}$ were centrifuged at $3000 \mathrm{rev} / \mathrm{min}$ for $15 \mathrm{~min}$, the supernatant was decanted and the cell pellet was resuspended and washed with 1 $\mathrm{mL}$ phosphate buffered saline using mechanical agitation. This washing was repeated three times. Then about $100 \mu \mathrm{L}$ standardized antihuman globulin reagent (anti-IgG) was added to the final pelleting in each test tube. The pellet was re-suspended and incubated in a water bath at $37^{\circ} \mathrm{C}$ for $48 \mathrm{~h}$. On examination agglutination was seen visually by using an agglutinoscope or on a slide under the microscope. The most important antigens available for the diagnosis of brucellosis are the smooth (S) Lipopolysaccharides (LPS) of the outer membrane and internal proteins. The Coombs test detects antibodies reacting against S-LPS which leads to agglutination and remains positive longer than other agglutination tests. The test was performed at the Veterinary Research Institute, Ipoh, Malaysia. All those who tested positive to brucellosis using the test were defined as cases.

\section{DATA ANALYSIS}

Data generated was first analysed using descriptive analysis with frequency tabulations of variables and then univariate logistic regression analysis of the variables studied. At this screening level, the significance of each factors was evaluated at $\alpha=0.10$. Variables that were considered important biologically were recruited into the multiple logistic regression model.

Logistic regression (enter method) was used to elucidate significant risk factors at $90 \%$ confidence level using IBM SPSS version 20 (SPSS Inc, Chicago, IL). Independent variables were tested for multicollinearity using a Tolerance Factor (TF) of 0.1 which corresponds to a Variance Inflation Factor (VIF) of 10 and among those with significant multicollinearity only one of such group in each case was chosen. Several combinations of factors were considered in the multivariable analysis in accordance with biological plausibility and the statistical significance of the univariate analysis by adding and removing variables until the best model is found. Only main effects were considered and the relevance of a variable was measured by the significance of its regression coefficient and quantified by the odds ratio (OR). Non-significant predictors were excluded from the logistic regression model.

All participants who were active in animal farming were categorized as farmers. All staffs in the veterinary department were considered as veterinary technical staff but all other individuals whose occupation was not indicated on the questionnaires were classified as others. The categories were further collapsed into two for easy analysis as farmers and non-farmers. The states were collapsed into two for the purpose of analysis as Selangor state and other states (Pahang and Negeri Sembilan).

The mean age of participants was used to categorize the respondents into two categories (younger being 40 years and less and older those above 40 years). Those with an income greater than RM2500 were categorized as high income earners and those with an income less than or equal to RM2500 were categorized as low income earners based on the consideration of the overall Malaysian economy and minimum income levels and purchasing power (Zulkifi $\&$ Bujang 2008). Majority of our respondents were the ethnic Malays. Other ethnicities such as Chinese, Indian, Orang Asli (the aborigines), Indonesian and foreigners who were in small numbers were collapsed into one category as others and compared to the Malays.

\section{RESULTS}

A total of 446 volunteers participated in this study. The mean age of all participants in the study was $40.62 \pm 13.11$ (range: $15-80)$. Six (1.35\%) individuals out of 446 were seropositive for brucellosis of which $5(2.69 \%)$ were farmers, $1(0.94 \%)$ was grouped as other individuals and none of the veterinary technical staff were positive (Table 1). Most of the farmers claimed to keep more than one animal at a time typically keeping goats, sheep and cattle and sometimes chicken so it was difficult to classify them based on animals they keep. The male respondents were in the majority $(84.08 \%$ ) compared to the females (15.92\%). All those seropositive were males. Based on marital status $347(77.80 \%)$ of the respondents were married while 99 $(22.20 \%)$ were single. A total of $4(1.15 \%)$ out of the married were seropositive for brucellosis, while 2 (2.02\%) were singles.

Based on educational qualifications, 312 (69.96\%) had secondary school education or below secondary school qualifications while 134 (30.04\%) had above secondary school qualifications. A total of 4 (1.28\%) were positive for brucellosis among those with secondary or below education level and $2(1.49 \%)$ among those with above secondary school education. Based on monthly income, 69 $(15.47 \%)$ had a monthly income of greater than RM2500 (high) and $377(84.53 \%)$ had a monthly income below or equal to RM2500 (low). A total of 2 (2.90\%) participants 
TABLE 1. Seroprevalence of human brucellosis in Selangor, Pahang and Negeri Sembilan, Malaysia

\begin{tabular}{cccc}
\hline Occupation & $\begin{array}{c}\text { Total } \\
\mathrm{N}\end{array}$ & $\begin{array}{c}\text { Seroprevalence } \\
\mathrm{n}(\%)\end{array}$ & $\begin{array}{c}95 \% \\
\mathrm{CI}\end{array}$ \\
\hline Farmers & 186 & $5(2.69)$ & $1.19,4.19$ \\
Vet. Technical Staff & 154 & $0(0.00)$ & $0.0,0.0$ \\
Others & 106 & $1(0.94)$ & $0.04,1.84$ \\
Total & 446 & $6(1.35)$ & $0.28,2.42$ \\
\hline
\end{tabular}

in the high income category were positive for brucellosis compared to $4(1.06 \%)$ positive in the low income category. Based on occupation, $186(41.70 \%)$ of the respondents were farmers and $260(58.30 \%)$ belong to the category of non-farmers (veterinary technical staff and others with unspecified occupation).

Most farmers, 251 (56.28\%) had assisted livestock during parturition while 195 (43.72\%) have not. Out of those who assisted livestock during parturition 5 (1.99\%) were positive for brucellosis and those who did not only $1(0.51 \%)$ were positive for brucellosis. A total of 185 $(41.48 \%)$ have cleaned aborted materials previously and $261(58.52 \%)$ have not. Among those who cleaned aborted materials $4(2.16 \%)$ were positive for brucellosis and among those who have never cleaned aborted materials 2 $(0.77 \%)$ were positive for brucellosis. Unpasteurized milk was consumed by $139(31.17 \%)$ while $307(68.83 \%)$ do not consume unpasteurized milk. Among those who consume unpasteurized milk 4 (2.88\%) were positive for brucellosis and among those who do not consume unpasteurized milk $2(0.65 \%)$ were positive for brucellosis. Among the participants, 135 (30.27\%) lived adjacent to a livestock farm while the remaining $311(69.73 \%)$ do not. Among those who live adjacent to a livestock farm, 3(2.22\%) were positive for brucellosis and among those who do not live adjacent to a livestock farm also $3(0.96 \%)$ were positive for brucellosis. A total of 120 (26.91\%) have had one or more symptoms related to brucellosis while $326(73.09 \%)$ have not. Surprisingly none of those who claim to have brucellosis related symptoms were positive for brucellosis while the remaining total positive cases of $6(1.84 \%)$ were among those who profess not to have any symptoms of brucellosis. Based on knowledge of acquiring brucellosis as a zoonotic disease $144(32.29 \%)$ knew they can get brucellosis while the remaining $(67.71 \%)$ were ignorant. Among those who knew they could get brucellosis 2 $(1.39 \%)$ were positive while among those who claimed not to know, $4(1.32 \%)$ were positive. Based on age categories $214(47.98 \%)$ were less than or equal to 40 years of age while $232(52.02 \%)$ were greater than 40 years of age. Majority of the positive cases (5) were among people less than 40 years of age $(2.34 \%)$ compared to only $1(0.43 \%)$ positive for brucellosis among those older than 40 years of age. Based on race $83(18.61 \%)$ of the respondents were Non-Malays (Chinese, Indian, Orang Asli, Indonesia and other foreigners) while $363(81.39 \%)$ were Malays. Among the non-Malays $2(2.41 \%)$ were positive for brucellosis compared to the Malays with 4 (1.10\%) positive for brucellosis. Univariate analysis revealed 2 significant variables at $90 \%$ confidence level (Table 2).

The multivariable logistic regression analysis showed that of all the predictors included into the model which are gender, marital status, educational level, monthly income, occupation, assisting during parturition, cleaning aborted materials, drinking unpasteurized milk, living adjacent goat farms, suffering any symptoms of brucellosis, knowledge about brucellosis, age, race and states; only occupation, age and drinking unpasteurized milk were considered significant risk factors at $90 \%$ confidence level in the final model. The logistic regression analysis showed that the odds of brucellosis increased 7.2 times (AOR 7.19, $90 \% \mathrm{CI}=1.16,44.71)$ in farmers compared with the nonfarmers, about 7.2 times (AOR 7.17, 90\% CI=1.16, 44.41) in younger individuals compared with the older and about 4.5 times (AOR 4.45, 90\% CI= 1.03, 19.15) in those who drank unpasteurized milk compared with those who did not (Table 3).

\section{DISCUSSION}

Brucellosis is an occupationally-associated disease and reports from different parts of the world have shown that one of the high risk groups for brucellosis are livestock farmers (Ahmad et al. 1999; Bamaiyi 2016; El Sherbini et al. 2007; Jama'ayah et al. 2011). The findings in this study showed that farmers had a higher seroprevalence of brucellosis than veterinary technical staff which may due to the better preventive and precautionary measures usually taken by veterinary staff when handling animals based on their knowledge of routes of transmission of disease. The univariate analysis showed that Selangor, which can be considered more urban than the other states sampled (Negeri Sembilan and Pahang), had a higher seroprevalence of human brucellosis. Similar observations were made in Kampala, Uganda where a higher seroprevalence of brucellosis of $83.5 \%$ was reported from urban areas and it was concluded in that that living in an urban area was a risk factor for brucellosis in man (Makita et al. 2008). This higher seroprevalence level is made possible because lots of unpasteurized milk is transported from periurban and rural areas to the urban areas for human consumption (Makita et al. 2008; Wanjohi et al. 2012) because of increased demands for milk and milk products which are considered good for human health. 


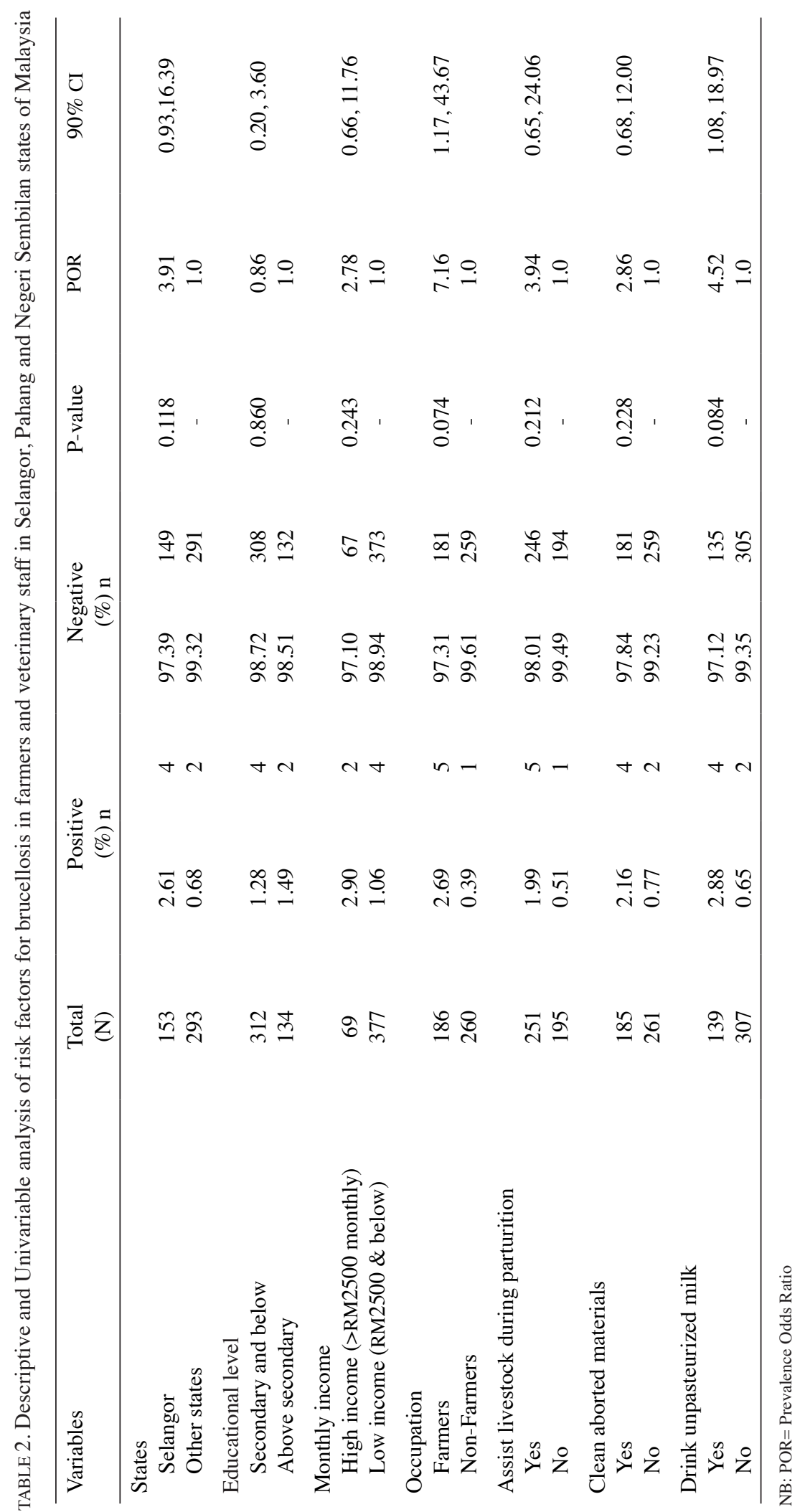




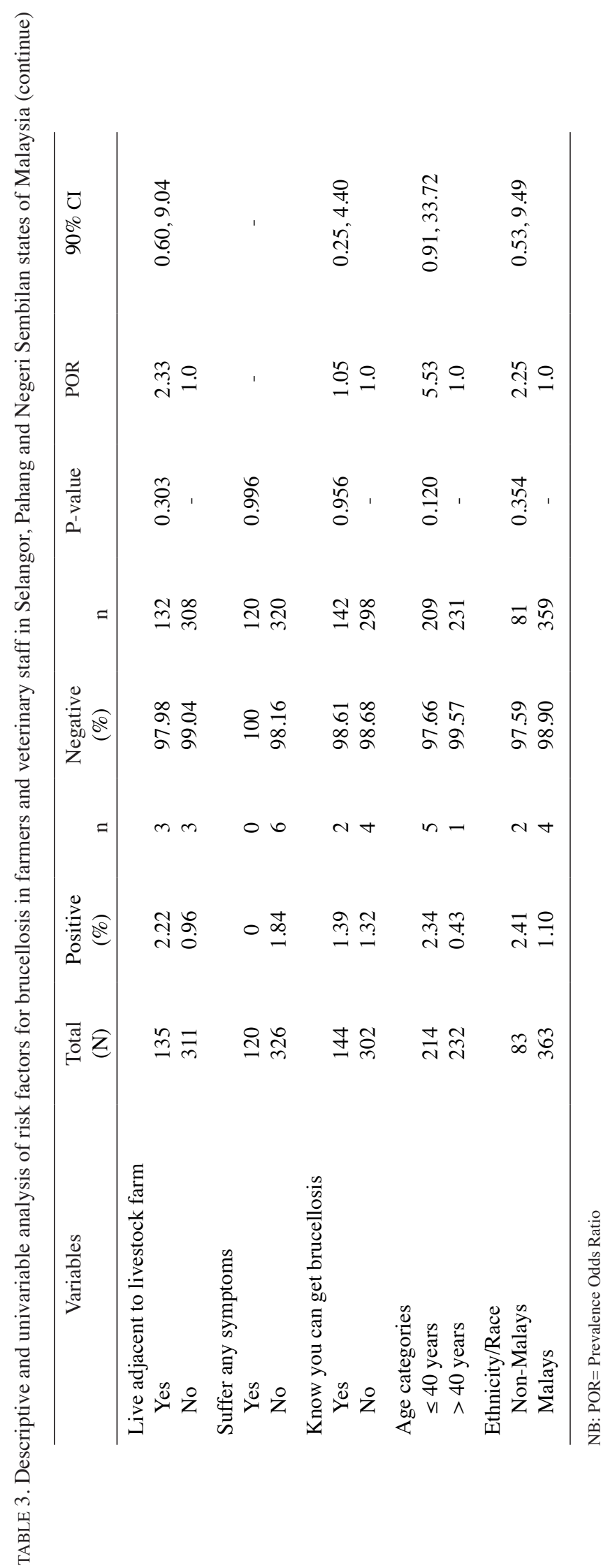


TABLE 4. Multiple Logistic regression analysis of risk factors for human brucellosis in Selangor, Pahang and Negeri Sembilan, Malaysia

\begin{tabular}{|c|c|c|c|c|c|c|}
\hline Variables & $\mathrm{B}$ & S.E. & Wald & Sig. & AOR & $90 \% \mathrm{CI}$ \\
\hline \multicolumn{7}{|l|}{ Occupation } \\
\hline Farmers & 1.973 & 1.111 & 3.157 & 0.076 & 7.19 & $1.16,44.71$ \\
\hline Non-farmers & - & - & - & - & 1.0 & - \\
\hline \multicolumn{7}{|l|}{ Age categories } \\
\hline Younger & 1.970 & 1.109 & 3.156 & 0.076 & 7.17 & $1.16,44.41$ \\
\hline Older & - & - & - & - & 1.0 & - \\
\hline \multicolumn{7}{|c|}{ Drink unpasteurized milk } \\
\hline Yes & 1.493 & 0.887 & 2.832 & 0.092 & 4.45 & $1.03,19.15$ \\
\hline No & - & - & - & - & 1.0 & - \\
\hline
\end{tabular}

Overall model data: $-2 \mathrm{LL}=51.949$; Nagelkerke $\mathrm{R}$ square $=0.194 ;$ Hosmer and Lemeshow Chi-square $=3.965 ; \mathrm{P}=0.681 ;$ d.f. $=6$ NB: $\mathrm{AOR}=$ Adjusted Odds Ratio; $\mathrm{CI}=$ Confidence Interval; Sig. $=$ Significance (P-value)

Educational level appears not to affect the seroprevalence of brucellosis. We believe that having higher level of education will not ensure protection against brucellosis but having the right information (regardless of education level) about brucellosis as well as taking heed to all precautionary measures against brucellosis is very important to guard against the infection. Those who had some knowledge of brucellosis and how to protect themselves from it have less seroprevalence of brucellosis because knowledge of the mode of transmission is protective as it helps individuals to take necessary precautionary measures to protect themselves from being infected by the bacteria (Kozukeev et al. 2006).

The higher income category has higher seroprevalence of brucellosis than the lower income in the univariate analysis. Contrary to previous findings of no difference related to income (Al-Shamahy et al.2000) it was found in this study that those with higher income had a higher odds of infection. We speculate that this may be due to the fact that the higher income farmers can afford to consume goat milk (which are relatively costly) rather than completely selling all milk produced in their farm. Farmers benefit greatly economically from selling dairy products of animals as a means of livelihood (Jelastopulu et al. 2008) and only the economically buoyant may afford to consume more of their products than sale for family subsistence and survival. Farmers in Malaysia, like any other developing countries, have modest income and live in rural areas. They usually keep goats for immediate financial needs and the milk is mostly consumed by the wealthier farmers and in more wealthier suburbs and estates (Yusuff 1985).

Most (83\%) of the seropositive cases in this study were farmers who rear goats and other livestock and hence have a closer level of relationship with animals. Close contact with infected animals significantly increases the farmer's risks for brucellosis (John et al. 2010). The non-farmers (veterinary technical staff, comprising of veterinarians and para-veterinary staff and others) who may or may not work with animals were less likely to be positive for brucellosis in our study. Non-farmers have less contact with infected animals and may be protected because of their increased knowledge of the mode of transmission of the infection thereby enabling them to take precautionary measures when handing animals. This agrees with a study from Kyrgyzstan who found that knowledge of the mode of transmission of brucellosis was a protective factor against infection (Kozukeev et al. 2006).

Most $(84 \%)$ of the farmers in the study and respondents were males and all the positive cases were also males. The high number of male respondents and farmers may partially account for the reason for the positive cases being male. The Malaysian livestock industry like in many other developing countries is dominated by males (Alston 1995; Dixon 1982) and men form the majority of farmers in Malaysia because of the physical nature of farming requiring more strength and energy (Ahmad 1999; Noor \& Dola 2011) exposing them to higher risks of brucellosis. In a study in Jordan the male gender was identified as a risk factor for brucellosis with odds of 2.5 (Al-Majali \& Shorman 2009).

Singles had a slightly higher seroprevalence than the married. Though no specific reason may be given for this, it is suggested that singles usually fall within the age range of the young who are reported to be more susceptible to brucellosis (Young 2009) due to their risky behaviours such as adventurous nature and tendency to handle animals more closely than the married.

Those who assisted goats during parturition previously as expected showed a higher seroprevalence of brucellosis due to the reproduction-associated nature of this zoonotic infection. The univariate analysis showed that the odds of brucellosis were 3.9 times more in those who assisted animals during parturition compared to those who did not. Copious amounts of Brucellae are usually shed during parturition by infected goats. These goats may appear apparently healthy but are carriers of the organism thereby increasing the chances of infection greatly at the time of parturition (Garin-Bastuji et al.2006). Assisting in parturition of such infected animals has on several cases been reported to lead to $B$. melitensis human infection (Earhart et al. 2009; Garin-Bastuji et al. 2006; Seleem et al. 2010). In addition, individuals who clean aborted 
materials were found to be at higher risk of infection with brucellosis because aborted materials from brucellosis infected animals contain high quantities of the infective bacteria (Chahota et al. 2003; Yumuk \& O'Callaghan 2012).

As expected, those who lived adjacent to goat farms had a higher seroprevalence rate for brucellosis and were more likely to come down with brucellosis because they are more likely to handle the animals due to their close proximity to the animals. Handling of animals and working closely with them is a risk factor for brucellosis reported by earlier works (Al-Shamahy et al. 2000; Hassanain \& Ahmed 2012; Meky et al. 2007; Sofian et al. 2008b).

Superficially, it may appear surprising that those who claimed to have symptoms of brucellosis had a lower seroprevalence rate or none compared to those who claimed to have no symptoms that had a higher seroprevalence rate. However the finding may be explained by the confusing nature of the disease symptoms to many other diseases that gave rise to symptoms such as headaches, fever, joint pains and back pains which are symptoms also common in other diseases such as malaria, dengue, Typhoid fever (Lopes et al. 2010; Pappas et al. 2006; Seleem et al. 2010). No specific reasons could be deduced for why the nonMalay races had a higher seroprevalence than the Malays but it is known that cultural differences and practices which exist among different races and groups of people may influence their rate of infection with brucellosis (John et al. 2010) as well as many other communicable diseases. It is probable that the Malays took more hygienic precautions that may have reduced their chances of infection due to the prevailing culture of washing hands and feet and other parts of the body often during a day for prayers and may be less in the habit of consuming raw milk. Other race, especially the traditional Chinese are known to recommend consuming goats milk raw to preserve the milks nutritional and medicinal properties which is said to be the most complete food known to man (Memish \& Balkhy 2004; Soultravelers 2013; Zhang et al. 2009) in spite of the apparent health risks that may be involved (Angulo et al. 2009).

The multivariable logistic regression model analysis showed that occupation, age categories and drinking unpasteurized milk account for $19.4 \%$ of the variability in the brucellosis infection in this study. Brucellosis is a common occupational and recreational infection that infects many people especially farmers in the Southeast Asian region and many regions of the world and has been in existence in this region for a long time (Kalimuddin et al. 2010; Seow et al. 2009). In Thailand, most of those affected were goat farmers similar to the Malaysian pattern in this study and a rapid rise in the infection coincided with the implementation of the government policy to promote goat rearing (Danprachankul et al. 2011; Manosuthi et al. 2004). In the years between 2004 and 2009 there have been 35 reported cases of brucellosis in humans in Thailand where it is a re-emerging disease (Danprachankul et al. 2011). In other parts of Asia such as India, caprine brucellosis is also associated with occupational hazards of those who work closely with goats (Mantur \& Amarnath 2008). Those who keep animals (farmers) are usually more prone to brucellosis than other individuals (Earhart et al. 2009). Brucellosis is very common (20.9\%) among farmers in Iran (Kassiri et al. 2013). These agree with the findings of this study that shows higher odds of brucellosis in farmers compared to non-farmers in Malaysia. It appears that animal farming is a major risk factor for brucellosis especially when farmers do not take necessary precautionary measures of hygiene when handling animals and their secretions.

Brucellosis can affect all ages but it is most common in adolescents and young adults (Al-Khafaji 2003; Gur et al. 2003). Consistent with the finding in the current study, in the developing countries most brucellosis cases are in the young and in developed countries it is mostly in adults (Yagupsky 2011). The individuals 40 years and younger had a higher odds of brucellosis than individuals older than 40 years in our study. Other workers have associated brucellosis with age (Al-Majali \& Shorman 2009; Al-Sultan et al. 2011). Higher risk for brucellosis were found more in ages 11-30 in a study in Yemen which also reported less brucellosis cases in humans older than 40 years (Al-Sultan et al. 2011) and in Turkey, which has 18000 new cases of brucellosis yearly (Arica et al. 2012), 63\% of brucellosis cases reported in humans were individuals between the ages of 15 and 45 years (Gur et al. 2003). In Greece 52 cases of childhood brucellosis in children aged between 0-14 years were reported in families of shepherds (Galanakis et al. 1996). In our study it is suggested that because those 40 years and below are in their most active working and adventurous years there is the tendency for them to have more opportunities of contact with the source of infection than those above 40 years who may be considered relatively less active and less adventurous (Young 2009). The activity and adventure of the younger individuals would imply them trying out unpasteurized milk and having contact with animals without adequate protective measures while the older individuals may be more inclined to be more cautious in trying such adventures. This age range may also be a reflection of the magnitude of the socio-economic and cultural impact of brucellosis as in some other countries such as Turkey (Gur et al. 2003) that makes certain age groups more prone to brucellosis infection, especially adolescents and young adults.

The consumption of unpasteurized milk is linked to higher odds of brucellosis and farmers who consumed such milk in our analysis indicated odds of 4.5 times more compared to those who consumed pasteurized milk. This supports the assertion of previous workers in this field who found that consumption of unpasteurized milk increases the odds of brucellosis 3.7 times (Sofian et al. 2008a) and up to 54.13 times (Earhart et al. 2009). Recently, there have been reports of outbreaks of brucellosis originating from Malaysia in Hong Kong due to the consumption of unpasteurized milk, which underscores the seriousness of this mode of transmission in the epidemiology of 
brucellosis in Asia (Anonymous 2011). There have also been cases of cluster infection among some local people in Penang, Malaysia after consuming unpasteurized milk from an infected goat farm herd (Anonymous 2011).

Brucellosis is present with a low seroprevalence rate among occupationally exposed farmers in Malaysia. In rural Greece health education of the population reduced the incidence of brucellosis from 1.4/1000/year to 0.2/1000/ year (Hadjichristodoulou et al. 1999) and same strategy can be applied in Malaysia.

\section{LIMITATIONS OF THE STUDY}

The low number of positive cases used for the logistic regression analysis may give rise to biases. Therefore, the results of this analysis should be interpreted with caution. The interpretation should take into cognisance the univariate analysis to have a balanced picture. The confidence level of $90 \%$ means our study has evidence at 0.10 Type I error which is not as strong as some studies that may have evidence at 0.05 Type I error, hence the need for caution when interpreting and drawing conclusions from our findings. However, in spite of the confidence level there is evidence of association of the risk factors with brucellosis. The occupation of some respondents is not indicated leading to classification among others which could be misleading as they must have been farmers or veterinary staff. This arose as an oversight on the side of trained personnel who administered the questionnaires. Due to these limitations, all interpretations should be made within the context of these limitations.

\section{ACKNOWLEDGEMENTS}

The authors wish to acknowledge all the staff of the Ministry of Health Malaysia and the Department of Veterinary Services of Malaysia for their cooperation and untiring efforts towards the success of this study. The farmers and other volunteers who took part in this study are acknowledged for their patience and cooperation. The authors are grateful to Puan Nur Eliyana binti Mohd Redhuan for translating the abstract into Bahasa Melayu. The authors declare that they have no conflict of interest.

\section{REFERENCES}

Ahmad, A. 1999. Participation of Malaysian women in Development. In Empowering Women: Key to Third World Development, edited by Samanta, R.K. New Delhi: M.D. Publications. pp. 33-68.

Ahmad, R., Naz, N.A. \& Freeha. 1999. Brucella infection in humans. Pakistan Veterinary Journal 19(1): 1999.

AL-Khafaji, J.K.T. 2003. Brucellosis among human populations in AL-Musaib district, Babylon province/Iraq. AL-Mustansiryia Science Journal 14(1): 1-5.

Al-Majali, A.M. \& Shorman, M. 2009. Childhood brucellosis in Jordan: Prevalence and analysis of risk factors. International Journal of Infectious Diseases 13(2): 196-200.

Al-Shamahy, H., Whitty, C. \& Wright, S. 2000. Risk factors for human brucellosis in Yemen: A case control study. Epidemiology and Infection 125(2): 309-313.
Al-Sultan, I.I., Ali, T.I. \& Ibrahim, O.E. 2011. Incidental occurence and risk factors of brucellosis in teaching hospital. Journal of Advanced Medical Research 1(1): 1-7.

Alston, M. 1995. Women and their work on Australian farms. Rural Sociology 60(3): 521-532.

Angulo, F.J., LeJeune, J.T. \& Rajala-Schultz, P.J. 2009. Unpasteurized milk: A continued public health threat. Clinical Infectious Diseases 48(1): 93-100.

Anon. 2011. Malaysia: Livestock Pupulation 2005-2010. Vol. 2011, Department of Veterinary Services, Ministry of Agriculture, Putrajaya, Malaysia.

Anonymous. 2011. Brucellosis remains unseen in Taiwan for 33 years; Taiwan CDC confirms two imported cases of brucellosis within two weeks. Vol. 2012, Center for Disease Control, R.O.C. (Taiwan), Center for Disease Control, R.O.C. (Taiwan).

Arica, V., Şilfeler, İ., Arica, S., Tutanç, M., Motor, V. \& İnci, M. 2012. Brucellosis with very high ferritin levels: Report of five cases. Human \& Experimental Toxicology 31(1): 104-106.

Bamaiyi, P.H. 2016. Prevalence and risk factors of brucellosis in man and animals-a review. International Journal of One Health 2: 29-34.

Bamaiyi, P.H., Hassan, L., Khairani-Bejo, S. \& Zainal, M.A. 2014. Updates on brucellosis in Malaysia and southeast Asia. Malaysian Journal of Veterinary Research 5(1): 71-82.

Bamaiyi, P.H., Hassan, L., Khairani-Bejo, S., Zainal, M.A., Ramlan, M., Krishnan, N., Adzhar, A., Abdullah, N., Hamidah, N.H.M., Norsuhanna, M.M. \& Hashim, S.N. 2012. Isolation and molecular characterization of Brucella melitensis from seropositive goats in Peninsula Malaysia. Tropical Biomedicine 29(4): 513-518.

Bikas, C., Jelastopulu, E., Leotsinidis, M. \& Kondakis, X. 2003. Epidemiology of human brucellosis in a rural area of northwestern Peloponnese in Greece. Eur. J. Epidemiol. 18(3): 267-274.

Bunnell, T. 2004. Malaysia, Modernity and the Multimedia Super Corridor: A Critical Geography of Intelligent Landscapes. London \& New York: Routledge.

Casao, M.A., Navarro, E. \& Solera, J. 2004. Evaluation of Brucellacapt for the diagnosis of human brucellosis. Journal of Infection 49(2): 102-108.

Chahota, R., Sharma, M., Katoch, R., Verma, S., Singh, M., Kapoor, V. \& Asrani, R. 2003. Brucellosis outbreak in an organized dairy farm involving cows and in contact human beings, in Himachal Pradesh, India. Veterinarski Arhiv 73(2): 95-102.

Danprachankul, S., Chiewchanyont, B., Appassakij, H. \& Silpapojakul, K. 2011. Brucellosis as an emerging disease in Thailand: A report of three cases with review of literatures. Journal of Health Science 18(5): 643-649.

Dawood, H.A. 2008. Brucellosis in Camels (Camelus dromedorius) in the south province of Jordan. American Journal of Agricultural and Biological Sciences 3(3): 623626.

Dixon, R.B. 1982. Women in agriculture: Counting the labor force in developing countries. Population and Development Review 8(3): 539-566.

Earhart, K., Vafakolov, S., Yarmohamedova, N., Michael, A., Tjaden, J. \& Soliman, A. 2009. Risk factors for brucellosis in Samarqand Oblast, Uzbekistan. International Journal of Infectious Diseases 13(6): 749-753.

El Sherbini, A., Kabbash, I., Schelling, E., El Shennawy, S., Shalapy, N., Elnaby, G.H., Helmy, A.A. \& Eisa, A. 2007. 
Seroprevalences and local variation of human and livestock brucellosis in two villages in Gharbia Governorate, Egypt. Transactions of the Royal Society of Tropical Medicine and Hygiene 101(9): 923-928.

Galanakis, E., Bourantas, K.L., Leveidiotou, S. \& Lapatsanis, P.D. 1996. Childhood brucellosis in north-western Greece: A retrospective analysis. European Journal of Pediatrics 155(1): 1-6.

Garin-Bastuji, B., Blasco, J.M., Marín, C. \& Albert, D. 2006. The diagnosis of brucellosis in sheep and goats, old and new tools. Small Ruminant Research 62(1-2): 63-70.

Gur, A., Geyik, M.F., Dikici, B., Nas, K., Cevik, R., Sarac, J. \& Hosoglu, S. 2003. Complications of brucellosis in different age groups: A study of 283 cases in southeastern Anatolia of Turkey. Yonsei Medical Journal 44(1): 33-44.

Hadjichristodoulou, C., Soteriades, E., Goutzianna, G., Loukaidou, M., Babalis, T., Antoniou, M., Delagramaticas, J. \& Tselentis, Y. 1999. Surveillance of brucellosis in a rural area of Greece: Application of the computerised mapping programme. Eur. J. Epidemiol. 15(3): 277-283.

Hassanain, N.A. \& Ahmed, W.M. 2012. Sero-prevalence of brucellosis in Egypt with emphasis on potential risk factors. World Journal of Medical Sciences 7(2): 81-86.

Jama'ayah, M.Z., Heu, J.Y. \& Norazah, A. 2011. Seroprevalance of brucellosis among suspected cases in Malaysia. Malaysian J. Pathol. 33(1): 31-34.

Jelastopulu, E., Bikas, C., Petropoulos, C. \& Leotsinidis, M. 2008. Incidence of human brucellosis in a rural area in Western Greece after the implementation of a vaccination programme against animal brucellosis. BMC Public Health 8(1): 241.

John, K., Fitzpatrick, J., French, N., Kazwala, R., Kambarage, D., Mfinanga, G.S., MacMillan, A. \& Cleaveland, S. 2010. Quantifying risk factors for human Brucellosis in rural Northern Tanzania. PLoS One 5(4): e9968.

Kalimuddin, S., Seow, C.J., Barkham, T., Deepak, R.N., Li, L. \& Tan, T.T. 2010. Hidden health risks of the Hajj - A report of two cases of brucellosis contracted by pilgrims during the Hajj. Scand. J. Infect. Dis. 42(3): 228-230.

Kassiri, H., Amani, H. \& Lotfi, M. 2013. Epidemiological, laboratory, diagnostic and public health aspects of human brucellosis in western Iran. Asian Pacific Journal of Tropical Biomedicine 3(8): 589-594.

Khairani-Bejo, S., Ardhy-Ardnan \& Bahaman, A.R. 2006. Investigation of canine Brucellosis in Klang Valley Malaysia. Journal of Animal and Veterinary Advances 5(1): 42-44.

Kozukeev, T.B., Ajeilat, S., Maes, E. \& Favorov, M. 2006. Risk factors for Brucellosis in Leylek and Kadamjay Districts, Batken Oblast, Kyrgyzstan, January-November, 2003. CDC MMWR 55(SUP01): 31-34.

Lopes, L.B., Nicolino, R. \& Haddad, J.P.A. 2010. Brucellosis Risk factors and prevalence: A review. The Open Veterinary Science Journal 4: 72-84.

Makita, K., Fèvre, E.M., Waiswa, C., Eisler, M.C. \& Welburn, S.C. 2010. How human Brucellosis incidence in urban Kampala can be reduced most efficiently? A stochastic risk assessment of informally-marketed milk. PLoS One 5(12): e14188.

Makita, K., Fèvre, E.M., Waiswa, C., Kaboyo, W., De Clare Bronsvoort, B.M., Eisler, M.C. \& Welburn, S.C. 2008. Human Brucellosis in urban and peri-urban areas of Kampala, Uganda. Annals of the New York Academy of Sciences 1149(1): 309-311.
Manosuthi, W., Thummakul, T., Vibhagool, A., Vorachit, M. \& Malathum, K. 2004. Case report: Brucellosis: A re-emerging disease in Thailand. The Southeast Asian Journal of Tropical Medicine and Public Health 35(1): 109-112.

Mantur, B.G. \& Amarnath, S.K. 2008. Brucellosis in India - A review. Journal of Biosciences 33(4): 539-547.

Meky, F., Hassan, E., Abd-Elhafez, A., Aboul-Fetou, A. \& ElGazali, S. 2007. Epidemiology and risk factors of brucellosis in Alexandria governorate. Eastern Mediterranean Health Journal 13(3): 677-685.

Memish,Z.A. \& Balkhy,H.H. 2004. Brucellosis and international travel. Journal of Travel Medicine 11(1): 49-55.

Nagalingam, M., Shome, R., Balamurugan, V., Shome, B., NarayanaRao, K., Vivekananda, V., Isloor, S. \& Prabhudas, K. 2012. Molecular typing of Brucella species isolates from livestock and human. Tropical Animal Health and Production 44(1): 5-9.

Noor, K.B.M. \& Dola, K. 2011. Investigating training impact on farmers' perception and performance. International Journal of Humanities and Social Science 1(6): 145-152.

Pappas, G. 2010. The changing Brucella ecology: Novel reservoirs, new threats. International Journal of Antimicrobial Agents 36(Supplement 1): S8-S11.

Pappas, G., Papadimitriou, P., Akritidis, N., Christou, L. \& Tsianos, E.V. 2006. The new global map of human brucellosis. The Lancet Infectious Diseases 6(2): 91-99.

Sam, I.C., Karunakaran, R., Kamarulzaman,A., Ponnampalavanar, S., Syed Omar, S.F., Ng, K.P., Mohd Yusof, M.Y., Hooi, P.S., Jafar,F.L. \& AbuBakar, S. 2012. A large exposure to Brucella melitensis in a diagnostic laboratory. Journal of Hospital Infection 80: 321-325.

Seleem, M.N., Boyle, S.M. \& Sriranganathan, N. 2010. Brucellosis: A re-emerging zoonosis. Veterinary Microbiology 140(3-4): 392-398.

Seow, C., Barkham, T., Wong, P., Lin,L., Pada, S.\& Tan, S. 2009. Brucellosis in a Singaporean with prolonged fever. Singapore Medical Journal 50(9): e312.

Shahaza, O., Khairani-Bejo, S., Zunita, Z. \& Bahaman, A.R. 2009. In-house rose Bengal Plate Agglutination Test (RBPT) for a rapid diagnosis of Brucellosis in goats in Malaysia. International Journal of Tropical Medicine 4(3): 116-118.

Sofian, M., Aghakhani, A., Velayati, A.A., Banifazl, M., Eslamifar,A.\& Ramezani, A. 2008a. Risk factors for human brucellosis in Iran: A case-control study. International Journal of Infectious Diseases 12(2): 157-161.

Sofian, M., Aghakhani, A., Velayati, A.A., Banifazl, M., Eslamifar, A. \& Ramezani, A. 2008b. Risk factors for human brucellosis in Iran: A case-control study. International Journal of Infectious Diseases 12(2): 157-161.

Soultravelers. 2013. Best Fresh Raw Goats Milk Penang, Malaysia. Vol. 2013.

Sullivan, K.M., Dean, A. \& Soe, M.M. 2009. OpenEpi: A webbased epidemiologic and statistical calculator for public health. Public Health Rep. 124(3): 471-474.

Tiong-Sa, T., Phin-Keong, V., Kok-Eng, C., Wan-Hin, T. \& Seng, T.L. 2001. Geography of Malaysia. Malaysia: National Response Strategies to Climate Change. pp. 203-246.

$\mathrm{Vu}, \mathrm{T}$. 2007. Rethinking the traditional concept of livestock services: A study of response capacity in Thailand, Malaysia and Vietnam. Pro-Poor Livestock Policy Initiative 41: 1-60.

Wanjohi, M., Gitao, C. \& Bebora, L. 2012. The prevalence of Brucella spp. in camel milk marketed from North Eastern 
Province, Kenya. In College of Agriculture and Veterinary Sciences Repository 4028, Vol 2013, University of Nairobi, Kenya, Nairobi, Kenya.

Yagupsky, P. 2011. Pediatric Brucellosis: An (almost) forgotten disease. In Hot Topics in Infection and Immunity in Children VIII (Advances in Experimental Medicine and Biology Vol. 719), edited by Curtis, N., Finn, A. \& Pollard, A.J. New York: Springer. pp. 123-132.

Young, E.J. 2009. Brucellosis. In Bacterial Infections of Humans, edited by Brachman, P.S. \& Abrutyn, E. New York: Springer. pp. 177-188. doi:10.1007/978-0-387-09843-2_8

Yumuk, Z. \& O'Callaghan, D. 2012. Brucellosis in Turkey - An overview. Int. J. Infect. Dis. 16(4): e228-e235.

Yusuff, M.K.M. 1985. The problems of goat production in Malaysia. In Goat Production and Research in the Tropics: Workshop held at the University of Queensland, Brisbane, Australia, 6-8 February 1984, Vol. 7 (edited by Copland, J.W.), Australian Center for International Agricultural Research (ACIAR), University of Queensland, Brisbane, Australia. pp. 4-14.

Zhang, H., Wang, J., Menghebilige, Chen, Y., Yun, Y., Sun, T., Li, H. \& Guo, M. 2009. Nutritive composition of Tarag, the traditional naturally-fermented goat milk in China. Ecology of Food and Nutrition 48(2): 112-122.

Zulkifi, Z. \& Bujang, A.A. 2008. Housing affordability: A study on household expenditures ratio to the income for the lower and medium income groups. In Sustaining Housing Market, edited by Abdullah, S. \& Zarin, H.A. UTM Malaysia: Penerbit UTM Press. pp. 26-41.

P.H. Bamaiyi, L. Hassan* \& S. Khairani-Bejo Department of Pathology and Microbiology Faculty of Veterinary Medicine

Universiti Putra Malaysia

43400 UPM Serdang, Selangor Darul Ehsan

Malaysia

M. ZainalAbidin

Department of Agribusiness and Information System

Faculty of Agriculture

Universiti Putra Malaysia

43400 UPM Serdang, Selangor Darul Ehsan

Malaysia
A. Adzhar \& N. Mokhtar

Department of Veterinary Services

62630 Putrajaya, Federal Territory

Malaysia

M. Ramlan \& P. Chandrawathani

Veterinary Research Institute

31400 Ipoh, Perak Darul Ridzuan

Malaysia

N. Hamidah

Department of Veterinary Services

40630 Shah Alam, Selangor Darul Ehsan

Malaysia

N. Abdullah

Department of Veterinary Services

71770 Seremban, Negeri Sembilan Darul Khusus Malaysia

A.M. Husna Maizura

Disease Control Division, Zoonosis Section

Ministry of Health

62590 Putrajaya, Federal Territory

Malaysia

P.H. Bamaiyi

Department of Public Health

School of Allied Health Sciences

Kampala International University Western Campus

Uganda

*Corresponding author; email: latiffah@upm.edu.my

Received: 3 March 2016

Accepted: 7 November 2016 